Received: $12 / 03 / 2019$

Revision: $27 / 09 / 2019$

Accepted: 05/10/2019

OnlineFirst:03/01/2020

\title{
Variables that Influence the Intention to Persist in Vocational Education
}

\section{Thanapat Sripan}

$\mathrm{PhD}$ candidate, King Mongkut's University of Technology Thonburi, Thailand, thanapat.sri@mail.kmutt.ac.th

\section{Chuchai Sujivorakul}

Asst. Prof., King Mongkut's University of Technology Thonburi, Thailand, chuchai.suj@kmutt.ac.th

This study explored variables that influence students' intention to persist in vocational education. The variables considered included self-regulation strategies, school participation, self-determination, school identification and teacher autonomy. These variables have been previously studied in other contexts but not in vocational education. Data collection involved self-report surveys with 277 vocational learners (age 15) from three vocational schools in Bangkok, Thailand. Pearson's correlation was used to test possible relationship among variables. Regression analysis identified the variables that were significant. School participation, self-determination and school identification were the three variables identified that influenced intention to persist. Self-regulation strategies, promotion of task-related discussion and teacher autonomy support did not have a significant influence on the intention to persist in school.

Keywords: self-regulation strategies, school participation, school identification, selfdetermination, intention to persist, vocational education, task-related discussion

\section{INTRODUCTION}

Rapid increases in attrition in vocational education run contrary to the increasing demands for labour in the industrial sector (De Witte, Cabus, Thyssen, Groot, \& van Den Brink, 2013). The difference between supply and demand negatively affects governments' ability to make policies related to economic sustainability. In the United States, vocational education drop-out rates have only slightly improved since 2000 (Field, Merrill, \& Morgan-Klein, 2010) for many reasons. First, there is the diversity of the standards in high school (Cataldi, KewalRamani \& Chapman, 2009); second, there is a difference in learners such as nationality, age, grade entrance (Rumberger \& Lamb, 2003); third, there are different measurement and evaluation systems (Dalton, Glennie, \& Ingels, 2009). High drop-out rates in vocational schools may be caused by poverty

Citation: Sripan, T., \& Sujivorakul, C. (2020). Variables that Influence the Intention to Persist in Vocational Education. International Journal of Instruction, 13(2), 17-32. https://doi.org/10.29333/iji.2020.1322a 
and single parenthood and these affect the unemployment problem, political and social apathy, and crime (De Witte et al., 2013). Yi et al. (2015) investigated causes of dropout in upper-secondary technical and vocational education and training schools in China. They found a variety of variables including financial constraints and parents' migrant status. Dore and Lüscher (2011) identified a range of variables such as employment reasons, socio-economic status, abandonment without justification and incompatible timetable. Similarly, Nielsen (2016) argued that students drop out of school for a variety of reasons and that schools and researchers need to pay more attention to these varying causes of dropping out.

In order to fully understand attrition and dropping out of school, one must take into account the notion and theoretical connotations of what is called students' 'intention to persist.' Intention to persist refers to intentions to continue one's schooling or dropping out of school (Hardre \& Reeve, 2003). According to Hang, Kaur, and Nur (2017) "Intentions to drop out referred to student aspiration or aim to finish or not to finish a programme of study" (p. 9). Intention to persist can be affected by various variables which may be internal or external to the student. For example, students' selfdetermination may also affect their intention to persist. Calvo et al. (2010) found a positive relationship between self-determination and dropping out in contexts of sport and exercise. School identification as an affective or emotional component of school engagement may also play a role. Archambault et al. (2009) found that global engagement (affective, behavioural and cognitive) predicted attrition. Similarly, Hadre and Reeve (2003) found that learners' school participation was significantly associated with intention to persist in school. External variables such as promotion of task-related discussion and teacher autonomy support can also affect drop-out rates and intention to persist. Previous research has shown that students who participate and discuss ideas with each other in class reported higher levels of school participation and engaged in higher levels of intention to persist in school (Wang \& Holcombe, 2010).

In Thailand where this study was conducted, high drop-out rates among vocational learners hamper efforts to produce skilled labor for the needs of business and the economy in general. As Nakornthap (2018) observed, problems with vocational education include students dropping out in order to engage in cheap unskilled labour, a lack of career counselling and of systemically planned career paths for vocational students. The high drop-out rate is in spite of the fact that the Thai government has made significant efforts to improve the quality of Thailand's education. For example, the National Economic and Social Development Plan (2007-2011), and the National Education Plan (2002 - 2016) have labour at the center of economic development. In Thailand, while primary education is compulsory, such is not the case for secondary education. The high-school level (upper secondary) is divided into an academic and vocational stream. Approximately $60 \%$ of students opt for academic education whereas $40 \%$ opt for vocational and students can enrol in either government or private vocational schools (Nakornthap, 2018). Government has implemented strategies to increase enrolment in vocational education in order to support the country's new economic reform plan. These strategies include introducing more competency-based curricula and more opportunities for experiential learning (Nakornthap, 2018). 
In general, in Thailand there has been little research on vocational education (CerdaNavarro, Sureda-Negre, \& Comas-Forgas, 2017) and even less on the phenomenon of dropping out of vocational education (Dore \& Lüscher, 2011). This is in spite of the fact that high student dropout rates are a problem globally (Tentshol, McNeil, \& Tongkumchum, 2019). Sahin et al. (2016) investigated absenteeism and drop-outs in Turkey at the primary, elementary and secondary school levels but their focus was not specifically on vocational education. Cerda-Navarro et al. (2017) argued in favour of a need for empirical evidence at this level "to help with making decisions about policies designed to curb the dropout rate in vocational education programs" (p. 1). It is with this gap in mind that the study reported on in this paper was conducted.

\section{Research Question}

How is the intention to persist in vocational education influenced by the following variables: self-regulation strategies; school participation; school identification; promotion of task-related discussion; self-determination and; teacher autonomy support?

\section{LITERATURE REVIEW}

This section provides an overview from the literature of the variables investigated in this study. These are: self-regulation (SR) strategies (SRS); school participation (SP); school identification (SI); promotion of task-related discussion (POD); self-determination (SD); teacher autonomy support (TAS).

\section{Self-Regulation Strategies}

$\mathrm{SR}$ is defined as a behaviour displayed by an individual who is behaviourally and motivationally active in his own learning process (Zimmerman, 2008). SRS involve independent, self-initiated learners capable of using a variety of learning strategies to accomplish learning goals (Fredricks, Blumenfeld, \& Paris, 2004; Zimmerman, 2008). According to Pintrich (2000), "self-regulation is an active, constructive process in which learners set goals for their learning and then attempt to monitor, regulate, and control their cognition, motivation, and behavior..." (p. 453). Theorists interested in selfregulation argue that students can regulate their own learning through active involvement learning and "thus can guide their thoughts, emotions, and actions in a way that positively affects their learning and motivation" (Boekaerts \& Corno, 2005, p. 3).

\section{School Participation}

As Fredricks et al. (2004) explained, SP is one of the components of school engagement and has also been linked with conduct and on-task behaviour. Engagement can be considered in terms of behavioural, emotional and cognitive engagement (Fredricks et al., 2004). Participation is part of behavioural engagement and includes involvement in academic and non-academic activities such as social or extracurricular activities and ranges from merely doing the work required to involvement in sports or school governance (Fredricks et al., 2004). In general, behavioural engagement includes students' behaviours that are directed at learning and includes positive conduct (e.g., attending class and completing schoolwork), involvement in learning and academic tasks (e.g., effort and concentration), and participation in extracurricular activities 
(Wang \& Holcombe, 2010, p. 634). Behavioural engagement relates directly to positive academic outcomes and preventing attrition (Fredricks et al., 2004).

\section{School Identification}

School identification is one of the three components of school engagement (Fredricks et al. 2004). Whereas school participation relates to the behavioural aspects of school engagement school identification relates to the emotional aspect. The behavioural and emotional domains are related since lack of participation in school activities can lead to emotional withdrawal and decreased school identification (Fredricks et al., 2004). "Participation and identification reciprocally influence each other" (Fredricks et al., 2004 , p. 72). School identification represents "a student's affective reactions and sense of identification with school" (Wang \& Holcombe, 2010, p. 634). Prior research found that school identification is an internal state with two components: internalized to the school: belonging and commitment (Wang \& Eccles, 2012). Some conceptualize it as identification with school (Fredricks et al., 2004). Wang and Eccles (2012) explained that it includes positive reactions in the classroom, personal identification and belonging in school. Wang and Holcombe (2010, p.652) found that that teachers' support can best promote students' positive identification with school.

\section{Promotion of Task-Related Discussion}

POD refers to students' perceptions that teachers encourage students to interact and discuss ideas with one another during class (Wang \& Holcombe, 2010). According to Patrick, Ryan, and Kaplan (2007) "POD creates affordances for students to justify, evaluate, and refine their ideas; to evaluate other possibilities; and to give and receive help" (p. 85). Such discussion has been associated with increased school participation, metacognition (Wang \& Holcombe, 2010) and with increased self-regulation (Wigfield \& Guthrie, 2000). Patrick, Ryan, and Kaplan (2007) explained the importance of POD in relation to the need for students to practice social skills by relating to their peers and regulating and controlling their own behaviour.

\section{Self-Determination}

SD is a theory of motivation relevant to contexts of learning (Khalkhali, Sharifi, \& Nikyar, 2013). Ryan and Deci (2000) argued that the theory explains the psychological processes underlying "optimal functioning and health" (p. 262). In a context of learning, these processes involve satisfaction of "basic psychological needs as they pursue and attain their valued outcomes" (p. 227). If their needs are not satisfied, then there may be negative consequences related not only to students' educational performance but also to their mental health (Ryan \& Deci, 2000). SD theory is underpinned by basic psychological needs including the need for autonomy and self-direction, the need to feel competent and effective and the need to connect with and relate to others (Legault, 2017). Ryan and Deci (2000) explained that intrinsic motivation and self-regulation of extrinsic motivation can result in positive experiences and performance as well as better mental health. They also explained that when needs are frustrated or not met, intrinsic motivation can decline, thus resulting in lower experience, poorer performance, and compromised wellness. 


\section{Teacher Autonomy Support}

TAS allows students to act upon their personal interests and values (Reeve, 2009). Teachers can create an autonomy supportive or controlling learning environment (Reeve \& Jang, 2006) that will decrease students' school distraction and, to a greater degree, increase their school identification (Wang \& Holcombe, 2010). Reeve (2006) found that students whose teachers offered both "high freedom and high structure" were more motivated and engaged in their learning (p. 232). According to Hardre and Reeve (2003) teachers' support of students' interests results in fewer dropout intentions. When students' autonomy is supported by teachers, students' motivation and learning will be greater (Reeve, 2006).

\section{METHOD}

\section{Research Design}

This study relied on survey research. Survey research involves examining the relationships among variables of given aspects of a portion of the population to generalize to the population as a whole (Kraemer \& Dutton, 1991). There were six dependent variables: self-regulation strategies, school participation, school identification, promotion of task-related discussion, self-determination and teacher autonomy support. The independent variable of this study was the intention to persist in vocational education.

\section{Participants}

The participants provided consent to participate according to the ethics' requirements of the university in which the principal investigator was enrolled. Convenience sampling was used to select schools and respondents. Participants were first-year students (15 years old) in the Vocational Certificate level from three technical colleges in, Bangkok. The sample size was determined by using Cochran's (1977) formula requiring a minimum sample of 250 . The researchers distributed the self-report survey to 280 vocational education students. Two-hundred seventy-seven (98.93\%) students returned the survey. Of this population, $194(70.0 \%)$ were male and the remaining $83(30.0 \%)$ were female.

\section{Procedures and Instruments}

Data collection was by self-report survey. The survey was distributed in the classroom outside of class time. It was completed using pencil and paper. The survey consisted of 38 items. Items were adapted from the following sources: Self-regulation strategies (Eccles et al., 1993); School participation, School identification and Promotion of taskrelated discussion (Wang \& Holcombe, 2010); Self-determination (Vallerand et al., 1997); Teacher autonomy support and Intention to persist (Hardre \& Reeve, 2003). This self-report survey was sent to three experts for verification of the content validity and for the index of consistency (IOC). The self-report survey was piloted with a sample group of students $(\mathrm{N}=30)$, and the overall reliability of the instrument was equal to 0.84 . This study used seven variables, namely; self-regulation strategies (SRS), school participation (SP), school identification (SI), promotion of task-related discussion 
(POD), self-determination (SD), teacher autonomy support (TAS), and intention to persist (ITP). The survey was compiled using a rating scale (see tables $1 \& 2$ ). The reliability coefficient for each variable of SRS), SP, SI, POD, SD, TAS, and ITP were $0.783,0.767,0.788,0.824,0.936,0.916$, and 0.865 , respectively. Based on the coefficient value, it can be concluded that the instrument used to measure the seven variables was reliable.

\section{Data Analysis}

To analyse quantitative data, all the statistical procedures were conducted using SPSS version 17.0. Pearson Product-Moment Correlation (Kurtz \& Mayo, 1978) was used to test possible relationships between multiple variables. Regression analysis was used to identify the significant variables. Multiple regression "enables the researcher to obtain a reduced set of variables from a larger set of predictors, eliminating unnecessary predictors, simplifying data, and enhancing predictive accuracy" (Halinski \& Feldt, 1970, p. 151)

\section{FINDINGS}

Overall results with percentages are presented in Tables 1 and 2. Regarding self regulation, results revealed that only a minority $(16-29 \%)$ did not engage in selfregulation strategies. For school participation, there were similar percentages of students who did and did not engage in school participation. For school identification, those in the almost never to rarely category were in the minority (i.e., $13-30 \%$ ). Similarly for promotion of task-related discussion, only a minority (21-25\%) were in the almost never or rarely category. 
Table 1

Results for SRS, SP, SI, and POD

\begin{tabular}{|c|c|c|c|c|c|}
\hline \multirow[b]{2}{*}{ Self-Regulation Strategies } & 1 & 2 & 3 & 4 & 5 \\
\hline & \multicolumn{5}{|l|}{$\%$} \\
\hline $\begin{array}{l}\text { How often do you try to relate what you are studying to other things you know } \\
\text { about? }\end{array}$ & 16 & & 40 & 44 & \\
\hline $\begin{array}{l}\text { How often do you try to plan what you have to do for homework before you get } \\
\text { started? }\end{array}$ & 24 & & 34 & 42 & \\
\hline $\begin{array}{l}\text { How often do you try to decide what you are supposed to learn, rather than just } \\
\text { read the material? }\end{array}$ & 20 & & 39 & 41 & \\
\hline \multirow[t]{3}{*}{ How often do you check your homework to make sure it's done correctly? } & 29 & & 35 & 36 & \\
\hline & 1 & 2 & 3 & 4 & 5 \\
\hline & \multicolumn{5}{|l|}{$\%$} \\
\hline How often do you find that it is hard for you to get homework done? & 33 & & 32 & 34 & \\
\hline $\begin{array}{l}\text { How often do you start daydreaming or thinking about something else when you } \\
\text { are in school? }\end{array}$ & 43 & & 34 & 23 & \\
\hline $\begin{array}{l}\text { How often do you have trouble in school because it is hard for you to sit for a long } \\
\text { time? }\end{array}$ & 39 & & 38 & 23 & \\
\hline
\end{tabular}

time?

\begin{tabular}{|c|c|c|c|c|c|}
\hline \multirow[b]{2}{*}{ School Identification } & 1 & 2 & 3 & 4 & 5 \\
\hline & \multicolumn{5}{|l|}{$\%$} \\
\hline How often do you feel you like school a lot? & 13 & & 33 & 54 & \\
\hline How often would you recommend other kids to go to the school you attend? & 16 & & 34 & 50 & \\
\hline How often do you feel that a good education is the best way to get ahead in life? & 17 & & 39 & 44 & \\
\hline How often do you feel that you belong to the school you attend? & 19 & & 39 & 42 & \\
\hline $\begin{array}{l}\text { How often do you feel that you learn more useful things from friends and relatives } \\
\text { than from school? }\end{array}$ & 20 & & 38 & 42 & \\
\hline How often do you feel that you have to do well in school to be successful in life? & 24 & & 39 & 37 & \\
\hline \multirow[t]{3}{*}{ How often do you feel that schooling is not so important? } & 30 & & 27 & 43 & \\
\hline & 1 & 2 & 3 & 4 & 5 \\
\hline & \multicolumn{5}{|l|}{$\%$} \\
\hline How often is there a lot of classroom discussion about what you are learning? & 21 & & 37 & 42 & \\
\hline How often do students get to discuss their work in class? & 18 & & 45 & 37 & \\
\hline How often are students' ideas and suggestions used during classroom discussions? & 25 & & 43 & 32 & \\
\hline
\end{tabular}

1 = Almost never, 2 = Rarely, 3 = Sometimes, 4 = Usually, 5 = Almost always

Table 2 presents the results for self-determination (SD), intention to persist (ITP) and teacher autonomy support (TAS). Notable results include that only $24 \%$ intended to dropout and only $10 \%$ felt that their teachers did not respect them. Thirty percent did indicate that they would not go to school if they had a choice. 
Table 2

Results for SD, TAS, and ITP

\begin{tabular}{|c|c|c|c|c|c|c|c|}
\hline \multirow[b]{2}{*}{ Self-Determination } & 1 & 2 & 3 & 4 & 5 & 6 & 7 \\
\hline & \multicolumn{7}{|l|}{$\%$} \\
\hline I go to school, because, basically, I have to. It's required. & \multicolumn{3}{|l|}{54} & 25 & \multicolumn{3}{|c|}{21} \\
\hline I go to school to just get through it. & \multicolumn{3}{|l|}{52} & 16 & \multicolumn{3}{|c|}{32} \\
\hline I go to school because, if I didn't go, I'd get in trouble or be punished. & \multicolumn{3}{|l|}{48} & 20 & \multicolumn{3}{|c|}{32} \\
\hline I wouldn't go to school if I really had a choice about it. & \multicolumn{3}{|l|}{56} & 14 & \multicolumn{3}{|c|}{30} \\
\hline \multirow[b]{2}{*}{ Intention to Persist } & 1 & 2 & 3 & 4 & & 5 & 6 \\
\hline & \multicolumn{7}{|l|}{$\%$} \\
\hline I sometimes consider dropping out of school. & \multicolumn{3}{|l|}{51} & 22 & \multicolumn{3}{|c|}{27} \\
\hline I sometimes feel unsure about continuing my studies. & \multicolumn{3}{|l|}{52} & 21 & \multicolumn{3}{|c|}{27} \\
\hline I intend to drop out of school. & \multicolumn{3}{|l|}{61} & 15 & \multicolumn{3}{|c|}{24} \\
\hline \multirow[b]{2}{*}{ Teacher Autonomy Support } & 1 & 2 & 3 & 4 & & 5 & 6 \\
\hline & \multicolumn{7}{|l|}{$\%$} \\
\hline My teachers don't show me respect. & \multicolumn{3}{|l|}{69} & 21 & \multicolumn{3}{|c|}{10} \\
\hline My teachers don't encourage me to ask questions. & \multicolumn{3}{|l|}{55} & 27 & \multicolumn{3}{|c|}{18} \\
\hline $\begin{array}{l}\text { When I offer suggestions to my teachers, they don't listen carefully or } \\
\text { consider my suggestions seriously. }\end{array}$ & \multicolumn{3}{|l|}{51} & 25 & \multicolumn{3}{|c|}{24} \\
\hline $\begin{array}{l}\text { I am not able to share my feelings with my teachers about what I want to } \\
\text { become. }\end{array}$ & \multicolumn{3}{|l|}{47} & 24 & \multicolumn{3}{|c|}{29} \\
\hline $\begin{array}{l}\text { My teachers don't convey their confidence in my ability to become what I } \\
\text { want to become. }\end{array}$ & \multicolumn{3}{|l|}{43} & 34 & \multicolumn{3}{|c|}{23} \\
\hline I don’t feel understood by my teachers. & \multicolumn{3}{|l|}{43} & 30 & \multicolumn{3}{|c|}{27} \\
\hline $\begin{array}{l}\text { My teachers don't try to understand how I see things before they suggest } \\
\text { how they would handle a particular situation. }\end{array}$ & \multicolumn{3}{|l|}{42} & 33 & \multicolumn{3}{|c|}{25} \\
\hline My teachers don't provide me with choices and options. & \multicolumn{3}{|l|}{37} & 39 & 24 & & \\
\hline
\end{tabular}

1 = Completely untrue, 2 = Untrue, 3 = Somewhat untrue, $4=$ Somewhat true, $5=$ True, $6=$ Very true, $7=$ Extremely true

Tables 3 and 4 present a summary of the correlations and regression analysis of variables related to intention to persist. As can be seen in Table 3 in relation to the associations of the variables, zero-order correlations were calculated. In terms of the outcomes of interest, the results indicated that an intention to persist in school was positively related to school participation $(\mathrm{r}=.367, \mathrm{p}<.01)$ and self-determination $(\mathrm{r}=$ $.600, \mathrm{p}<.01)$. Intention to persist in school was negatively related to self-regulation strategies $(\mathrm{r}=-.187, \mathrm{p}<.01)$ and promotion of task-related discussion $(\mathrm{r}=-.150, \mathrm{p}<$ $.05)$.

Table 3

Correlations between Variables

\begin{tabular}{|c|c|c|c|c|c|c|c|}
\hline & SRS & SP & SI & POD & SD & TAS & ITP \\
\hline SRS & - & $-.152^{*}$ & $.421^{\text {*** }}$ & $.507^{* * *}$ & $.284^{* * *}$ & $.403^{* * *}$ & $-.187^{k * *}$ \\
\hline SP & & - & -.110 & $-.277^{* *}$ & $-.403^{* * *}$ & -.098 & $.367^{\text {*** }}$ \\
\hline SI & & & - & $.399^{* *}$ & $.163^{\text {** }}$ & $.345^{* *}$ & .029 \\
\hline POD & & & & - & $.235^{* * *}$ & $.583^{* *}$ & $-.150^{*}$ \\
\hline SD & & & & & - & .118 & $.600^{* * *}$ \\
\hline TAS & & & & & & - & -.042 \\
\hline ITP & & & & & & & \\
\hline
\end{tabular}

SRS = self-regulation strategies, $\mathrm{SP}=$ school participation, SI school identification, POD promotion of discussion, SD self-determination, TAS teacher autonomy support, ITP intention to persist. $* p<.05 ; * * p<.01$ 
Regression analysis was conducted to examine the extent to which self-regulation strategies, school participation, school identification, promotion of task-related discussion, self-determination and teacher autonomy support relate to the intention to persist in school. The results of the analysis are shown in Table 4 and Figure 1. These results highlight the significance of self-regulation strategies, school participation, school identification, promotion of task-related discussion, self-determination and teacher autonomy support in predicting the intention to persist in school. Selfdetermination is the strongest predictor for intention to persist in school $(\beta=.542, \mathrm{p}<$ $.01)$. Furthermore, school identification and school participation support the intention to persist in school $(\beta=.169, \mathrm{p}<.01),(\beta=.152, \mathrm{p}<.01)$ respectively.

Table 4

Multiple Regression Analysis

\begin{tabular}{llrrr}
\hline Dependent variable & Independent variables & Beta & \multicolumn{2}{c}{ Parameter estimates } \\
\cline { 3 - 5 } & & & $\mathrm{t}$ & $\mathrm{p}$ \\
\hline Intention to persist & Self-regulation strategies & -.080 & -1.370 & .172 \\
& School participation & .152 & 2.875 & $.004^{* *}$ \\
& School identification & .169 & 3.137 & $.002^{* *}$ \\
& Promotion of task-related & -.021 & -.324 & .747 \\
& discussion & & & $.000^{* *}$ \\
& Self-determination & .542 & 10.202 & .696 \\
\hline
\end{tabular}

$* p<.05 ; * * p<.01$

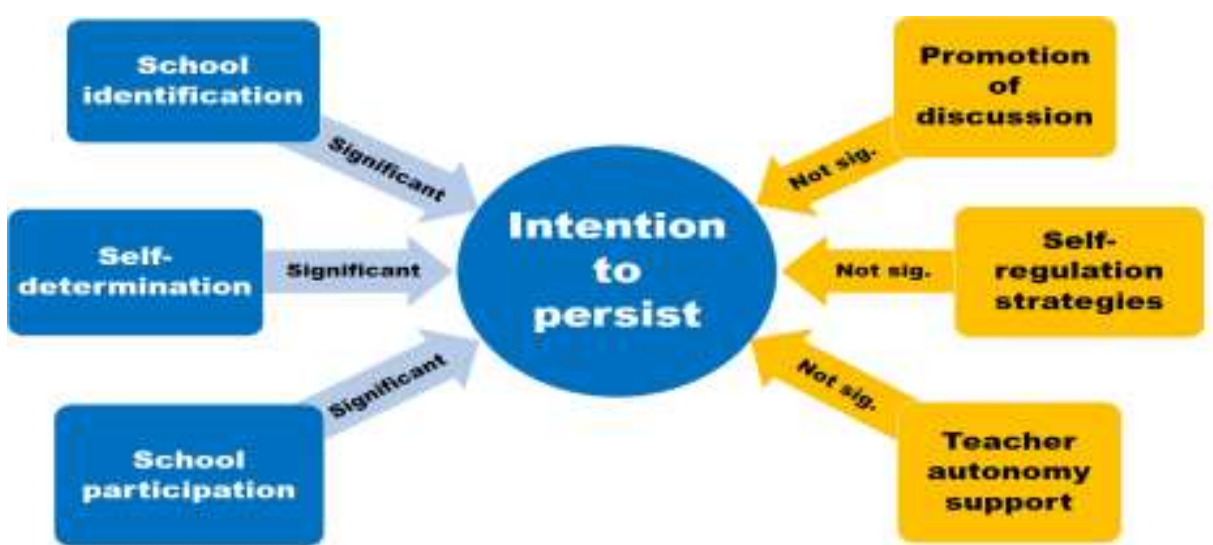

Figure 1

Summary of Variables Influencing Students' Intention to Persist.

\section{DISCUSSION}

This study investigated six variables that potentially influence intention to persist in vocational education. Results revealed that school participation, school identification and self-determination are three variables that influence intention to persist in vocational 
education. Self-regulation strategies, promotion of task-related discussion and teacher autonomy support did not have a significant effect on the intention to persist in school.

School participation had a statistically significant effect on intention to persist in vocational education. This result is consistent with those of Akbaşli, Arastaman, Gün, and Turabik (2019). The authors conducted a study of the relationship between school engagement and burnout (exhaustion) with 472 Turkish university students. The authors defined school engagement both in terms of the cognitive, behavioural (school participation) and emotional (school identification) dimensions. Their findings revealed a statistically significant relationship between students' level of school engagement and their burnout levels. The authors concluded that school engagement (including participation) is important for preventing burnout. Results of this study in relation to school participation are also similar to those of Malechwanzi and Hongde (2018). Their study investigated the relationship between school engagement (including identification) and college resources on learning outcomes. Participants were 430 Kenyan college students. Results showed that student engagement mediated both resources and learning outcomes. The authors suggested that "resources should be evaluated based on how they enhance student engagement" (p. 971). Ramshe, Ghazanfari, and Ghonsooly (2019) identified a relationship between personal goals and school engagement but they did not consider the effect of school engagement on intention to persist. However, like the other studies reviewed in this section, they identified the importance of school engagement.

Self-determination had a statistically significant effect on intention to persist in vocational education. Not surprisingly, Wehmeyer et al. (2012) noted that teachers should incorporate self-determination as part of instruction. However, as Denney and Daviso (2012) argued, many teachers lack both the knowledge and understanding to incorporate it effectively. Self-regulation strategies did not have a statistically significant effect on intention to persist in vocational education. Utvær and Haugan's (2016) Norwegian study found that regulation (as a measure of self-determination) was significantly correlated with school completion. The authors identified the importance of "supporting students' satisfaction of basic needs" in order to prevent dropping out (p. 35). Similarly, Balkis, Arslan, and Duru (2016) found that students with a lack of motivation self-regulation (among other variables) were more likely to have school absenteeism. The difference between their study and this one is that this study used a broader definition of self-determination whereas their study focused on self-regulation of motivation specifically.

Promotion of task-related discussion did not have a statistically significant effect on intention to persist in vocational education. Task-related (or task-based) discussion has, however, been gaining attention in the literature on social media and computer use (see Le Baron-Earle, 2013). Teacher autonomy support did not have a statistically significant effect on students' intention to persist in vocational education. This result is inconsistent with Hardre and Reeve (2003) and Hang et al. (2017) who found that teacher autonomy support enhanced students' motivation and perceptions of competence which, in turn, increased their intention to persist. Kaur et al. (2015) in Thailand identified beneficial effects of teacher autonomy support. However, their results were for grade 6, Thai, 
foreign-language learners as opposed to vocational learners and there was no attempt to associate the construct with intention to persist. Hang et al. (2015) found that administrator support resulted in enhanced motivation which in turn decreased students' intention to drop out. In relation to physical education courses at the post-secondary level, Behzadnia, Adachi, Deci, and Mohammadzadeh (2018) found a significant association between autonomy support and intention to persist. The difference in results between this study and theirs may be due to the level (college versus secondary) and the limited scope (vocational in general -all subjects versus physical education classes only.)

\section{CONCLUSION}

This study explored six variables that may influence intention to persist in vocational education as follows: self-regulation strategies; school participation; school identification; promotion of task-related discussion; self-determination and; teacher autonomy support. Participants were 277 vocational learners (age 15) from three Bangkok vocational schools. Pearson's correlation was used to test possible relationship among variables. Regression analysis identified the variables that are significant. School participation, self-determination and school identification are the three variables identified which influence intention to persist. Self-regulation strategies, promotion of task-related discussion and teacher autonomy support did not have a significant influence on the intention to persist in school.

\section{Limitations}

This study was limited to self-report measures which may not actually be a valid measure of students' actual behaviours. Future studies might involve investigations with those who actually dropped out in order to investigate those variables that affect intention to persist. This study was conducted in Thai vocational education where cultural variables and educational traditions may not be the same as those in other countries. In this regard, it will be up to the reader to generalise or not to his/her own context. This study examined the effect of pre-determined variables on the intention to persist. Future studies might take a more inductive approach in terms of identifying variables that affect attrition.

\section{Implications}

In terms of implications for practice, this study has shown that vocational learners with higher self-determination had higher intention to persist in school. Thus, to promote persistence, schools need to find ways to support students' self-determination. Hang et al. (2017) made suggestions for improving vocational students' SD. These suggestions include focusing on the learning environment to help students experience higher selfesteem, take responsibility for their behaviour as well as feeling connected to the school. Hang et al. (2017) also suggested that students should be made to feel competent in order to accept and master challenging tasks.

Learners with perceived higher levels of school identification also had higher intention to persist in school. As noted previously, school identification relates to the emotional 
aspect of school engagement. To improve learners' school identification, Cerda-Navarro et al. (2017) recommended that schools and teachers need to "cultivate positive relationships" as well as personalize learning by understanding and addressing students' problems (academic, social, or personal). Cerda-Navarro et al. (2017) also recommended that there be systematic monitoring of students' progress and strengthening their problem-solving skills. Tanggaard (2013) proposed that teachers and schools listen carefully and be sensitive to students" voices and to the "refrains" and the "puzzling stories" to better understand how students make sense of growing up, fitting in and becoming somebody (p. 436).

Learners with perceived higher levels of school participation also had higher intention to persist in school. Nielsen (2016) concluded in his study of learners in the Danish vocational education and training (VET) system that students' participation should be considered more broadly and not merely in terms of what happens in school. Instead, schools need to pay attention to students" "multi-contextual participation" at home and outside of school and how these are connected or disconnected. Nielsen (2016) further proposed that schools identify the barriers and facilitators of participation. Nielsen (2016) also noted the need for schools to help students integrate school-related tasks with those taking place outside of school. Lehr, Hanson, Sinclair, and Christenson (2003) proposed general strategies for preventing attrition in secondary school in general. These may be relevant in a context of vocational education. Their strategies include providing more guidance and support as well as flexibility in learning, focusing on the overall school culture and classroom climate and improving interpersonal relationships. As Salvà-Mut et al. (2014) concluded, the focus must not be limited to merely increasing student attendance. Instead, efforts must be made to support students who may feel marginalized so that they can better connect with their school. For an extensive list of recommendations see Cerda-Navarro et al. (2017). In general, those interested in reducing drop-out rates will need to pay attention to these and other recommendations if vocational education is to be successful.

\section{ACKNOWLEDGEMENTS}

This research was supported by three Technical Colleges under the Institute of Vocational Education, Bangkok. The conclusions drawn in this article are those of the authors and do not reflect the views of the Institute of Vocational Education, Bangkok.

\section{REFERENCES}

Akbaşli, S., Arastaman, G., Gün, F., \& Turabik T. (2019). School engagement as a predictor of burnout in university students. PAU Journal of Education, 45, 293-309.

Archambault, I., Janosz, M., Fallu, J. S., \& Pagani, L. S. (2009). Student engagement and its relationship with early high school dropout. J. of Adolescence, 32(3), 651-670.

Balkis, M., Arslan, G., \& Duru, E. (2016). The school absenteeism among high school students: Contributing variables. Edu. Sciences: Theory \& Practice, 16, 1819-1831.

Behzadnia, B., Adachi, P. J., Deci, E. L., \& Mohammadzadeh, H. (2018). Associations between students' perceptions of physical education teachers' interpersonal styles and 
students' wellness, knowledge, performance, and intentions to persist at physical activity: A self-determination theory approach. Psyc. of Sport \& Exercise, 39, 10-19.

Boekaerts, M., \& Corno, L. (2005). Self-regulation in the classroom: A perspective on assessment and intervention. Applied Psychology, 54(2), 199-231.

Calvo, T. G., Cervelló, E., Jiménez, R., Iglesias, D., \& Murcia, J. A. M. (2010). Using self-determination theory to explain sport persistence and dropout in adolescent athletes. The Spanish Journal of Psychology, 13(2), 677-684.

Cataldi, E. F., KewalRamani, A. and Chapman, C. (2009). High school dropout and completion rates in the United States: 2007 Compendium Report. NCES 2009064. National Center for Education Statistics.

Cerda-Navarro, A., Sureda-Negre, J., \& Comas-Forgas, R. (2017). Recommendations for confronting vocational education dropout: A literature review. Empirical Research in Vocational Education and Training, 9(1), 17-39.

Cochran, W. G. (1977). Sampling techniques. New York: John Wiley \& Sons.

Dalton, B., Glennie, E., \& Ingels, S. J. (2009). Late high school dropouts: characteristics, experiences, and changes across cohorts. Descriptive analysis report. NCES 2009-307. National Center for Education Statistics.

Denney, S.C. \& Daviso, A.W. (2012). Self-determination: A critical component of education. American Secondary Education, 40(2), 43-51.

De Witte, K., Cabus, S., Thyssen, G., Groot, W., \& van Den Brink, H. M. (2013). A critical review of the literature on school dropout. Edu. Research Review, 10, 13-28.

Dore, R., \& Lüscher, A. Z. (2011). Persistence and dropout in the vocational education high school in Minas Gerais. Cadernos de Pesquisa, 41(144), 770-789.

Eccles, J. S., Midgley, C., Wigfield, A., Buchanan, C. M., Reuman, D., Flanagan, C., \& Mac Iver, D. (1993). Development during adolescence: The impact of stageenvironment fit on young adolescents' experiences in schools and in families. American Psychologist, 48(2), 90-101.

Field, J., Merrill, B., \& Morgan-Klein, N. (2010). Researching higher education access, retention and drop-out through a European biographical approach: Exploring similarities and differences within a research team. In Proceedings of the European Society for Research on the Education of Adults, 6th European Research Conference, University of Linköping (pp. 23-26).

Fredricks, J. A., Blumenfeld, P. C., \& Paris, A. H. (2004). School engagement: Potential of the concept, state of the evidence. Review of Edu. Research, 74(1), 59-109.

Halinski, S. \& Feldt, S. (1970). The selection of variables in multiple regression analysis. Journal of Educational Measurement, 7(3), 151-157. 
Hang, B. T. T., Kaur, A., \& Nur, A. H. B. (2017). A self-determination theory based motivational model on intentions to drop out of vocational schools in Vietnam. Malaysian Journal of Learning and Instruction, 14(1), 1-21.

Hang, B. T. T., Kaur, A., \& Patil, A. (2015). Impacts of school administration autonomy support on students' learning motivation and intentions to drop out of vocational school. International Journal of Quality Assurance in Engineering and Technology Education (IJQAETE), 4(2), 1-12.

Hardre, P. L., \& Reeve, J. (2003). A motivational model of rural students' intentions to persist in, versus drop out of, high school. J of Educational Psychology, 95(2), 347-356.

Khalkhali, V., Sharifi, R., \& Nikyar, A. (2013). Students' intentions to persist in, versus dropout of high school: What self-determined motivation tells us about it? International Online Journal of Educational Sciences, 5(2), 282-290.

Kraemer, K. L., \& Dutton, W.H. (1991). Survey research in the study of management information systems. In K.L. Kraemer (Ed.), The information systems research challenge: Survey research methods, vol. 3 (pp. 3-58). Cambridge, MA: Harvard Business School Press.

Kurtz, A. K., \& Mayo, S. T. (1978). The nature of statistical methods. In A. K. Kurtz, \& S. T. Mayo (Eds.). Workbook for Statistical Methods in Education and Psychology (pp. 7-12). New York: Springer.

Le Baron-Earle, F. (2013). Social media and language learning: Enhancing intercultural communicative competence (Unpublished doctoral dissertation). University of Limerick.

Legault, L. (2017). Self-determination theory. In V. Zeigler-Hill, T. Shackelford (Eds.), Encyclopedia of personality and individual differences (pp.1-9). New York: Springer.

Lehr, C., Hanson, A., Sinclair, M., \& Christenson, S., (2003). Moving beyond dropout prevention towards school completion: an integrative review of data-based interventions. School Psychology Review, 32(3), 42-364.

Malechwanzi, J., \& Hongde, L. (2018). The relation between college resources and learning outcomes: considering the mediating effects of student engagement. Croatian Journal of Education-Hrvatski Casopis za Odgoj i Obrazavanje, 30(3), 903-937.

Nakornthap A. (2018). Rethinking Thai secondary education. In G. Fry (Ed.), Education in Thailand (pp. 125-161). Singapore: Springer.

Nielsen, K. (2016). Engagement, conduct of life and dropouts in the Danish vocational education and training (VET) system. Journal of Vocational Education \& Training, 68(2), 198-213.

Patrick, H., Ryan, A. M., \& Kaplan, A. (2007). Early adolescents' perceptions of the classroom social environment, motivational beliefs, and engagement. Journal of Educational Psychology, 99(1), 83-98. 
Pintrich, P. R. (2000). An achievement goal theory perspective on issues in motivation terminology, theory, and research. Contemporary Edu. Psychology, 25(1), 92-104.

Ramshe, M. H., Ghazanfari, M., \& Ghonsooly, B. (2019). The role of personal best goals in EFL learners' behavioural, cognitive, and emotional engagement. International Journal of Instruction, 12(1), 1627-1638.

Reeve, J. (2006). Teachers as facilitators: What autonomy-supportive teachers do and why their students benefit. The Elementary School Journal, 106(3), 225-236.

Reeve, J. (2009). Why teachers adopt a controlling motivating style toward students and how they can become more autonomy supportive. Edu. Psychologist, 44(3), 159-175.

Reeve, J., \& Jang, H. (2006). What teachers say and do to support students' autonomy during a learning activity. Journal of Educational Psychology, 98(1), 209-218.

Rumberger, R. W., \& Lamb, S. P. (2003). The early employment and further education experiences of high school dropouts: A comparative study of the United States and Australia. Economics of Education Review, 22(4), 353-366.

Ryan, R. M., \& Deci, E. L. (2000). Self-determination theory and the facilitation of intrinsic motivation, social development, and well-being. American Psyc., 55(1), 68-78.

Sahin, S., Arseven, Z., \& Kiliç, A. (2016). Causes of student absenteeism and school dropouts. International Journal of Instruction, 9(1), 195-210.

Salvà-Mut, F., Oliver-Trobat, M. F., \& Comas-Forgas, R. (2014). Abandono escolar y desvinculación de la escuela: Perspectiva del alumnado. Magis. Revista Internacional de Investigación En Educación, 6(13), 129-142.

Tanggaard, L. (2013). An exploration of students' own explanations about dropout in vocational education in a Danish context. J. of Voc. Edu. \& Training, 65(3), 422-439.

Tentshol, K., McNeil, R. \& Tongkumchum, P. (2019). Determinants of university dropout: A case of Thailand. Asian Social Science, 15(7), 49-56.

Utvær, B. K. S., \& Haugan, G. (2016). The academic motivation scale: dimensionality, reliability, and construct validity among vocational students. Nordic Journal of Vocational Education and Training, 6(2), 17-45.

Vallerand, R. J., Fortier, M. S., \& Guay, F. (1997). Self-determination and persistence in a real-life setting: Toward a motivational model of high school dropout. Journal of Personality and Social Psychology, 72(5), 1161-1176.

Wang, M. T., \& Eccles, J. S. (2012). Social support matters: Longitudinal effects of social support on three dimensions of school engagement from middle to high school. Child Development, 83(3), 877-895.

Wang, M.T., \& Holcombe, R. (2010). Adolescents' perceptions of school environment, engagement, and academic achievement in middle school. American Educational Research Journal, 47(3), 633-662. 
Wehmeyer, M.L., Shogren, K.A., Palmer, S.B., Williams-Diehm, K.L., Little, T., \& Boulton, A. (2012). The impact of the self-determined learning model of instruction in student self-determination. Exceptional Children, 78(2), 135-153.

Wigfield, A., \& Guthrie, J. T. (2000). Engagement and motivation in reading. Handbook of Reading Research, 3, 403-422.

Yi, H., Zhang, L., Yao, Y., Wang, A., Ma, Y., Shi, Y., \& Rozelle, S. (2015). Exploring the dropout rates and causes of dropout in upper-secondary technical and vocational education and training (TVET) schools in China. Int. J. of Edu. Dev., 42, 115-123.

Zimmerman, B. J. (2008). Investigating self-regulation and motivation: Historical background, methodological developments, and future prospects. American Educational Research Journal, 45(1), 166-183. 